\title{
Effects of revegetation on surficial soil salinity in panspot soils
}

\author{
D.G. HOPKINS, M.D. SWEENEY, D.R. KIRBY, AND J.L. RICHARDSON
}

\begin{abstract}
Panspots and transition zone panspots (slickspots) from a Leptic/Typic Natriboroll soil complex in western North Dakota were compared to determine the effects of secondary plant succession upon soil properties. Herbage and rooting characteristics were evaluated among panspot, transition zone, and adjacent wellvegetated Belfield soils using point frame data and a modified dry ashing technique. The effects of vegetation upon soil electrical conductivity (EC) were tested using gradient transects aligned perpendicular to boundaries between panspots and transition zones. Transition zones had $\mathbf{4 0 \%}$ more total forage and twice the litter found in panspot areas. Thirteen of 17 gradient transects showed an inverse relationship between soil EC and distance into transition zones at the 0 to $5 \mathrm{~cm}$ depth. Significantly higher rootmass was obtained in the 0 to $5 \mathrm{~cm}$ depth in transition zones compared to panspots. A conceptual model based on subsurface water flow is presented to explain the polygonal cracking that was observed only in transition zone surfaces initiating a series of interactions resulting in natural reclamation of the transition zone soil.
\end{abstract}

Key Words: secondary succession, panspots, surface crusts, salinity

Limited productivity of rangeland vegetation on soils having natric horizons has been extensively documented (Sandoval et al. 1959, Lewis and White 1964, Stuart et al. 1971, White et al. 1982). Inhibition of vascular plant growth on "panspot" (slickspot) soils is especially severe due to excessive salinity and sodicity which, in effect, create "physiologic deserts" in these areas (Lewis et al. 1959, Munn and Boehm 1983).

Research on panspots traditionally focused on the physical and chemical characteristics of panspot soils as components of sodiumaffected landscapes (Lewis et al. 1959, Johnson et al. 1985). Information on panspot vegetation has generally been limited to secondary observations made during such studies (Kellogg 1934, Mogen et al. 1959, Munn and Boehm 1983).

The identification and influence of natural vegetation dynamics on panspot soil properties has received little attention on the Northern Great Plains. Preliminary work in western North Dakota has indicated a potential relationship between secondary succession in panspots and improvements in surficial soil chemistry (Hopkins et al. 1987b).

In the field, we observed that 3 distinct range communities could be easily recognized in Natriboroll map units. Communities nearly devoid of vegetation were described as panspots. We noted earlier (Hopkins et al. 1987a) that soil surveyors often overestimate the extent of these soils because of their stark appearance. A second community, at the same elevation as panspots, supports sparse grasses and low growing half-shrubs; we refer to these areas as "transition zones". The third range community, classified as a clayey range site is found on Belfield soils. Belfield soils are at higher topographic positions than either panspots or transition zone soils.

This study was designed to test the hypothesis that zones of

\footnotetext{
Authors are research associate, associate professor, Department of Soil Science; associate professor, Department of Animal and Range Sciences; and professor,

Department of Soil Science, North Dakota State University, Fargo 58105.

Authors wish to thank Dr. Robert Carlson for assistance in statistical analysis.

Manuscript accepted 30 June 1990.
}

secondary plant succession in panspots (referred to hereafter as transition zones) modify soil electrical conductivity (EC) in the near-surface soil environment. The study objectives were to: (1) compare soil EC between panspot and transition zones, (2) evaluate surface and subsurface soil properties and inventory vegetation among panspot, transition zone, and adjacent Belfield soils, and (3) compare root density distributions between panspot, transition zone, and adjacent Belfield soils.

\section{Materials and Methods}

\section{Study Area}

The study area was on the Dickinson Experiment Station Ranch Headquarters approximately $40 \mathrm{~km}$ northwest of Dickinson, North Dakota in NE1/4, Sec. 16, T13N, R96W (Lat. 47 $12^{\prime} 30^{\prime \prime} \mathrm{N}$., Long. $102^{\circ} 51^{\prime} 20^{\prime \prime} \mathrm{W}$.). Soils with natric horizons are common in this region of western North Dakota (Wright et al. 1982). The study area was chosen to provide detailed soils information for an ongoing short duration grazing trial in Sec. 16 (Kirby et al. 1986) and because of the high concentration of panspots associated with the major soils (Hopkins et al. 1987a). A fence was constructed in early June 1987 to prevent cattle from grazing the study area.

The climate of the study is continental with mean annual precipitation of $425 \mathrm{~mm}$ and mean air temperature of $4.6^{\circ} \mathrm{C}$. About $80 \%$ of the annual precipitation falls between April and September. Mean annual snowfall is $965 \mathrm{~mm}$ but strong winds in the area keep most of the snow in drifts and the ground free of snow (Wright et al. 1982).

\section{Field Methods}

A 20 by $20-\mathrm{m}$ area was selected that encompassed unclassified panspot and transition zone soils interspersed in areas of Belfield soils (fine, montmorillonitic, Glossic Natriborolls). The range site designation for the Belfield soil is clayey; panspot and transition zone soils are mapped as thin claypan (USDA Soil Conservation Service 1984).

Vegetation was analyzed for species composition and basal area by the point frame method (Arny and Schmid 1942) with 500 points taken in representative sites for panspot, transition zone, and Belfield soil areas. Five replicate $0.25-\mathrm{m}^{2}$ quadrats were clipped in similar areas to compare herbaceous and shrub standing crop among soils. Clipped samples were oven dried and weighed. Vegetation nomenclature follows the Great Plains Flora Association (1986).

Intervals of $1 \mathrm{~m}$ were established for detailed mapping and sampling in the 20 by $20-\mathrm{m}$ study area. The soil surface was mapped and digitized to determine the extent of panspot, transition zone, and Belfield soils. A topographic map was made, based on 1-m observation intervals, using a surveyor's level. Slope ranges from 1 to $3 \%$ in the study area (Fig. 1). Detailed topographic data (9 points per $\mathrm{m}^{2}$ ) was obtained for several panspot areas having transition zones to determine if elevational differences were related to vegetation distribution or soil salinity in the panspots.

Panspots with transition zone areas large enough to accommodate a gradient transect were identified with the soil surface map. Seventeen transects, oriented perpendicular to the boundary between panspots and transition zones, were established. Sampling sites were marked off in $10-\mathrm{cm}$ increments from the boundary into 


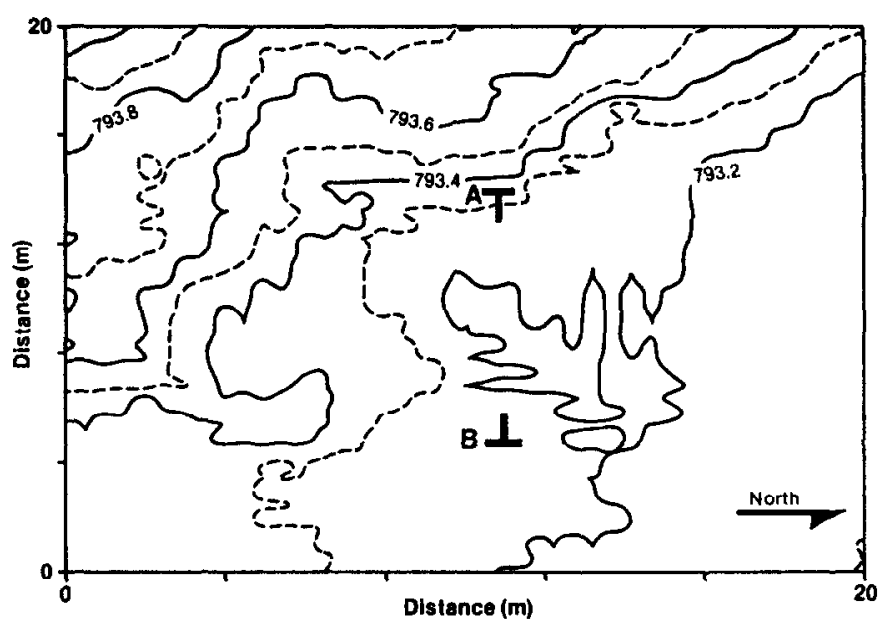

Fig. 1. Topographic map of study area with $1-\mathrm{dm}$ contour interval, Dunn County, North Dakota; elevations in meters above MSL. Boundaries for soil characterization trench are indicated by $\mathbf{A}$ and $\mathbf{B}$.

the 2 zones with an equal number of sites either side of the boundary. Between 3 and 9 sites were sampled depending on vegetation patterns in the panspots. Soils were sampled at each site in $5 \mathrm{~cm}$ depth increments to $30 \mathrm{~cm}$, using a $4.4 \mathrm{~cm}$ diameter soil probe. Care was taken in selecting transects to ensure that end members would not be affected by adjacent soils with different vegetation patterns. All samples were air dried and ground for laboratory analyses.

Soil profile descriptions of Belfield and panspot soils were taken in a trench dissecting the vegetation analysis sites, using standard methods of the National Cooperative Soil Survey (Soil Survey Staff 1951). Samples were collected, air dried, and ground for laboratory characterization.

Root density distributions in panspots and transition zones were evaluated using the gradient transect method described earlier. Four root gradient transects about $1 \mathrm{~m}$ in length were selected near the trench and sampled with a $6.3 \mathrm{~cm}$ diameter coring tube to $30 \mathrm{~cm}$ depth to obtain sufficient volume for laboratory analysis. Soil cores were extracted at $15-\mathrm{cm}$ intervals along the transects and carefully sliced in $5 \mathrm{~cm}$ depth increments to $15 \mathrm{~cm}$, with 1 sample taken from 15 to $30 \mathrm{~cm}$. Additionally, 8 sites were located randomly from the Belfield soil area to allow comparison of root density distribution among the panspot, transition zone, and Belfield soils. Root density samples were air dried for laboratory analysis.

\section{Laboratory Methods}

Soil electrical conductivity (EC) was determined on 1:1 soil/ water suspensions for all gradient transect samples (Dahnke 1980). The values for 1:1 EC are from a dilute suspension and only represent about one half of the more familiar saturated paste extract EC values. We used 1:1 suspensions because of the large number of samples and the fact that the relatively homogenous textures of the panspot soils minimize textural effects differentiating saturated paste extract EC from that of 1:1 suspensions (Hogg and Henry 1984).

Root density was determined following a method modified from Ward et al. (1978). Dry soil samples were weighed, placed in

Table 1. Cover (\%) of plant species for panspot, transition zone, and Belfield soils on the Dickinson Experiment Station Ranch Headquarters, North Dakota.

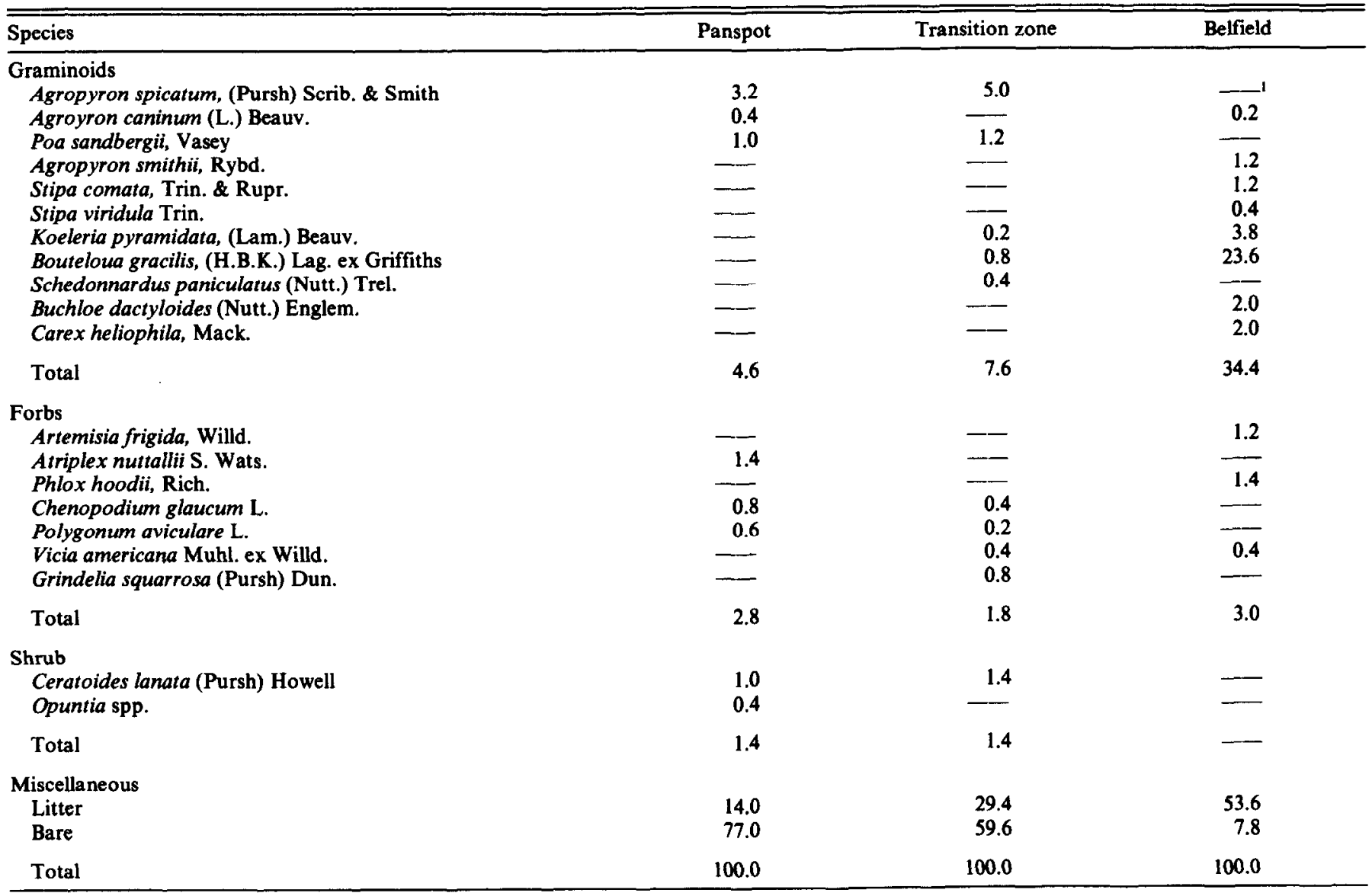

'Species did not occur. 
fine-meshed muslin cloth and wire-wrapped. Samples were immersed overnight in a water bath with sodium hexametaphosphate to disperse soil particles. Fine soil particles were separated from the sands by gently rubbing the sample under running water. Later, the bags were opened, placed on a 100 -mesh sieve, and the contents washed under running water. Roots and organic particles were separated from the sand fraction by a series of decantations. Washed root samples were placed in ashing crucibles and dried overnight at $60^{\circ} \mathrm{C}$. The dried samples were cooled, weighed, and placed in an ashing oven at $470^{\circ} \mathrm{C}$ for 6.5 hours, then cooled and weighed.

The ashing step was included because inspection of the samples revealed that mineral matter was tightly bound to root tissues even after several shakings and decantations. To correct for tightly bound mineral matter, several mineral-free subsamples of the same root tissues were obtained and ashed. From these subsamples the average root mass lost on ashing was found to be $77.7 \%$. The mass lost on ashing from samples containing mineral matter was divided by 0.777 to obtain a corrected dry root mass.

The 2 soils sampled in the trench were characterized in the laboratory using the following methods. Soluble salts were determined on saturated paste soil extracts using the methods of Rhoades (1982). Soil pH was determined potentiometrically (Peech 1965). Calcium, magnesium, and sodium, ( $\mathrm{Ca}, \mathrm{Mg}$, and $\mathrm{Na}$ ) were determined with atomic absorption spectroscopy using methods of Chapman and Pratt (1961). Adjusted sodium adsorption ratio (SAR adj) was calculated using concentrations of $\mathrm{Ca}, \mathbf{M g}$, and $\mathrm{Na}$ corrected for ion pairs and activities (Alzubaidi and Webster 1983) using the relationship established by the US Salinity Laboratory Staff (1954). The adjusted SAR provides a better estimate of sodium activity than SAR based on concentration alone. Organic carbon was determined using the Walkley-Black method modified by Chapman and Pratt (1961). Particle size analysis was determined by pipette method (Day 1965).

The EC data for the gradient transects were analyzed separately for each depth class using one-way analysis of variance with a covariate site along the transect (SAS Institute 1985). This approach was utilized as it provides an estimate of the effect of distance along the transect on soil EC. The presence of a functional relationship between transect site (distance) and EC for panspots and transition zone soils was assessed by assigning negative distance to sites on the panspot side of the boundary, and positive distance to the transition zone. This would generate an inverse relationship between EC and distance on the transects if salinity were lower in transition zones. The EC data were evaluated for (1) differences among transects, (2) a functional relationship with distance along transects, and (3) homogeneity of the functional relationship between transects, using one-way analysis of covariance. Root density data were analyzed using a $t$-Test (Harnett 1970).

\section{Results}

Panspot and transition zone soils were observed primarily below the 793.4-m contour interval shown in Figure 1; Belfield soils were found above this contour. The distribution of the 3 soils in the study area was 13,16 , and $71 \%$ for panspot, transition zone, and Belfield soils, respectively. Panspot and transition zone soils comprise almost $30 \%$ of the landscape and present a marked contrast to well-vegetated Belfield soils.

Transition zone soils exhibit a 2 fold increase in vegetative litter compared to panspots (Table 1), but plant basal area was similar for panspot and transition zone soils (8.8 and $10.8 \%$ respectively, Table 1). There was a trend for greater yields of graminoid species in transition zones compared to panspots (Table 2). The production and diversity of species from the Belfield soil was substantially
Table 2. Forage yield of panspot, transition zones, and Belfield soils on the Dickinson Experiment Station Ranch Headquarters, North Dakota.

\begin{tabular}{lccc}
\hline \hline Vegetation type & $\begin{array}{c}\text { Panspot } \\
\text { soil }\end{array}$ & $\begin{array}{c}\text { Transition } \\
\text { zone }\end{array}$ & $\begin{array}{c}\text { Belfield } \\
\text { soil }\end{array}$ \\
\hline Graminoid & $15(2.6)^{1}$ & $22(11.2)$ & $87(5.6)$ \\
Forb & $30(7.2)$ & $2(0.9)$ & $20(19.2)$ \\
Shrubs & $6(7.5)$ & $48(7.5)$ & $6(2.6)$ \\
Total & 51 & 72 & 113 \\
\hline
\end{tabular}

IStandard error.

greater than from either panspot or transition zone soils (Tables 1 and 2).

Differences in basal area and forage yield mentioned above are due to differences in edaphic properties of the Belfield and panspot soils. Belfield soils had more soil organic matter to greater depths than panspot soils and lower salinity and sodicity as evidenced by EC and SAR adj (Table 3). Depth to the C horizon of the Belfield soil was greater than in the panspot soil but both soils were underlain by highly saline siltstone.

Table 3. Selected soil morphologic, physical, and chemical properties of major soils of the study area. EC data represent about one half of saturated paste extract EC.

\begin{tabular}{|c|c|c|c|c|c|c|}
\hline Horizon' & $\begin{array}{l}\text { Depth } \\
(\mathrm{cm})\end{array}$ & $\begin{array}{l}\text { USDA } \\
\text { texture }\end{array}$ & \multicolumn{2}{|c|}{$\begin{array}{l}\text { Organic pH } \\
\text { matter (\%) }\end{array}$} & $\begin{array}{l}\mathrm{EC}^{3} \\
\mathrm{ds} \mathrm{m}^{-1} \\
\end{array}$ & SAR $_{\text {adj }}$ \\
\hline \multicolumn{7}{|c|}{ Panspot } \\
\hline Crust & $0-2$ & SiL & 1.5 & 7.5 & 2.8 & 24.0 \\
\hline $\mathbf{E}$ & $2-4$ & $\mathrm{SiC}$ & 1.8 & 7.4 & 6.0 & 32.7 \\
\hline Bty & $4-11$ & $\mathrm{SiC}$ & 1.6 & 7.7 & 15.6 & 59.1 \\
\hline $\mathrm{Cl}$ & $11-21$ & SiCL & 1.1 & 7.8 & 17.7 & 57.7 \\
\hline $\mathrm{C} 2$ & $21-50$ & $\mathrm{SiL}$ & 0.7 & 7.7 & 16.7 & 54.1 \\
\hline $\mathrm{Crl}$ & $50-64$ & SiL & 0.3 & 7.8 & 16.0 & 57.4 \\
\hline $\mathrm{Cr} 2$ & $64-74$ & SiL & 0.3 & 7.4 & 15.2 & 55.9 \\
\hline $\mathrm{Cr} 3$ & $74-110$ & SiL & 0.4 & 7.4 & 13.0 & 42.9 \\
\hline \multicolumn{7}{|c|}{ Belfield } \\
\hline E & $0-4$ & SiL & 6.6 & 7.3 & 2.0 & 2.3 \\
\hline EB & $4-27$ & $\mathrm{SiCL}$ & 2.5 & 7.2 & 0.4 & 1.3 \\
\hline BE & $27-34$ & $\mathrm{SiC}$ & 1.3 & 7.8 & 0.8 & 3.3 \\
\hline Btk1 & $34-51$ & $\mathrm{SiC}$ & 1.4 & 8.1 & 0.7 & 8.8 \\
\hline Btk2 & $51-65$ & SiCL & 1.1 & 8.0 & 4.8 & 25.4 \\
\hline $\mathrm{C}$ & $65-79$ & $\overline{\mathrm{SiCL}}$ & 1.0 & 7.9 & 13.2 & 40.5 \\
\hline $\mathrm{Cr} 1$ & $79-112$ & $\mathrm{SiCL}$ & 0.7 & 8.2 & 16.0 & 48.8 \\
\hline $\mathrm{Cr} 2$ & $112-148$ & $\mathrm{SiCL}$ & 0.6 & 7.9 & 14.9 & 49.8 \\
\hline
\end{tabular}

Inomenclature follows USDA/SCS standards

'Si-silt, L-loam, C-clay

1:1 soil/ water suspensions

Variations in salinity were large in the locality of the study area and even larger in panspot soils (Hopkins et al. 1987a). We generalized the data on salinity variability (as measured by EC) by pooling observations from all sampling sites and transects (Table 4). These data were stratified by depth class. Mean EC increases with depth, and standard errors usually decrease with depth.

The relationship between soil EC and site (distance on transects) was not consistent for transects in the study area (data not shown). Due to the presence of significant interaction, individual regression coefficients were calculated for each transect (Table 5). Soil EC and transect site were inversely related for the 0 to $5 \mathrm{~cm}$ depth class in 13 of 17 transects (Table 5) indicating that soil EC was lower in transition zones. The number of transects with negative regression coefficients decreases in lower depth classes. In 4 transects there was an increase in magnitude of negative coefficients in the second compared to the first depth class. 
Table 4. Variations in soil salinity of panspot and transition zone soils of the study area pooled for all transects by depth class.

\begin{tabular}{lccc}
\hline \hline $\begin{array}{c}\text { Depth midpoints } \\
\mathrm{cm}\end{array}$ & $\begin{array}{c}\text { Mean EC } \\
\text { dS m }^{-1}\end{array}$ & $\begin{array}{c}\text { Stanard } \\
\text { Deviation }^{1}\end{array}$ & $\begin{array}{c}\text { Standard } \\
\text { error }\end{array}$ \\
\hline 2.5 & 1.98 & 0.56 & 0.14 \\
7.5 & 5.39 & 1.33 & 0.32 \\
12.5 & 7.54 & 1.04 & 0.25 \\
17.5 & 8.59 & 0.72 & 0.18 \\
22.5 & 9.26 & 0.36 & 0.09 \\
27.5 & 9.62 & 0.41 & 0.10 \\
\hline
\end{tabular}

${ }^{1} n=102$

Table 5. Sample regression coefficients (b) for all gradient transects by depth class.

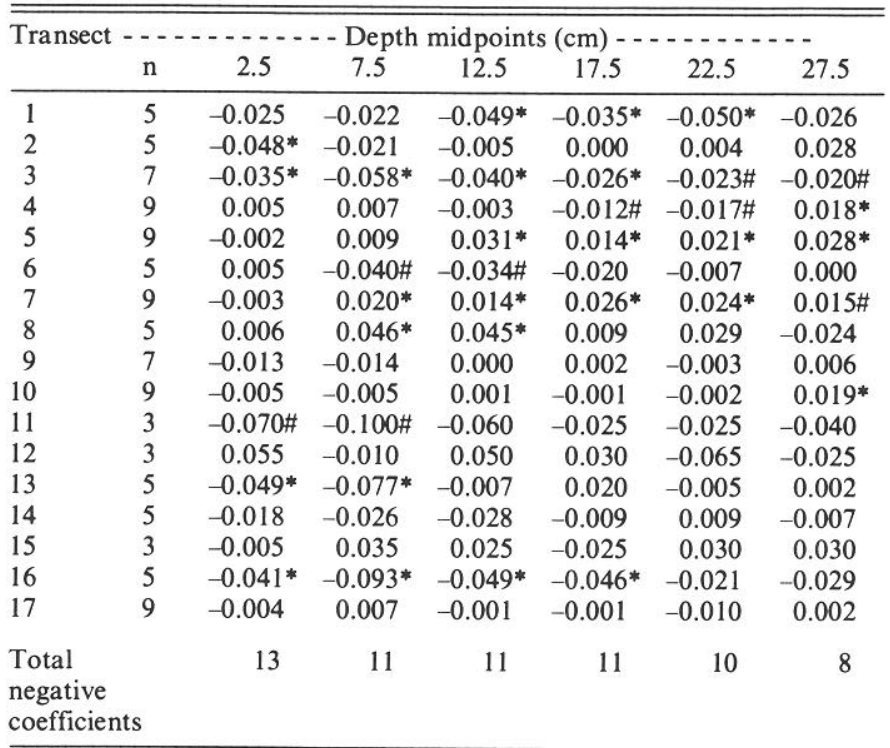

\# significant at the 0.10 level

* significant at the 0.05 level

Regression coefficients for transects 5, 7, and 8 deviated from the other transects; soil EC increases with distance into the transition zone at most depths. These transects appear responsible for the significant site-transect interaction in the overall analysis.

Mean rootmass for the 0 to $30 \mathrm{~cm}$ depth is $0.17,0.29$, and $1.39 \%$, respectively, for panspot, transition zone, and Belfield soils. Root density distributions were greater for all depth classes in transition zones compared to panspots but only the 0 to $5 \mathrm{~cm}$ depth showed significantly higher rootmass in transition zone soils (Table 6).

Table 6. Rootmass means (\% dry soil weight), standard deviations, and standard errors by individual and pooled depth classes for panspots (pan) and transition zone (transition) soils.

\begin{tabular}{|c|c|c|c|c|c|c|}
\hline \multirow{2}{*}{$\begin{array}{l}\text { Depth } \\
\text { class }\end{array}$} & \multicolumn{2}{|c|}{ Mean } & \multicolumn{2}{|c|}{ Standard Dev. } & \multicolumn{2}{|c|}{ Standard error } \\
\hline & Pan & Transition & Pan & Transition & Pan & Transition \\
\hline \multicolumn{7}{|l|}{$(\mathrm{cm})$} \\
\hline $0-5$ & 0.29 & $0.58^{1}$ & 0.08 & 0.25 & 0.08 & 0.16 \\
\hline $5-10$ & 0.21 & 0.25 & 0.04 & 0.07 & 0.06 & 0.07 \\
\hline $10-15$ & 0.10 & 0.14 & 0.03 & 0.07 & 0.03 & 0.04 \\
\hline $0-30$ & 0.16 & 0.25 & 0.09 & 0.03 & 0.04 & 0.07 \\
\hline
\end{tabular}

${ }^{1}$ significant at 0.10 level.

Incremental increases in rootmass with distance along transects were inconsistent (Fig. 2). Transect 3 illustrates a gradual increase in rootmass with distance into the transition zone, but transect 4

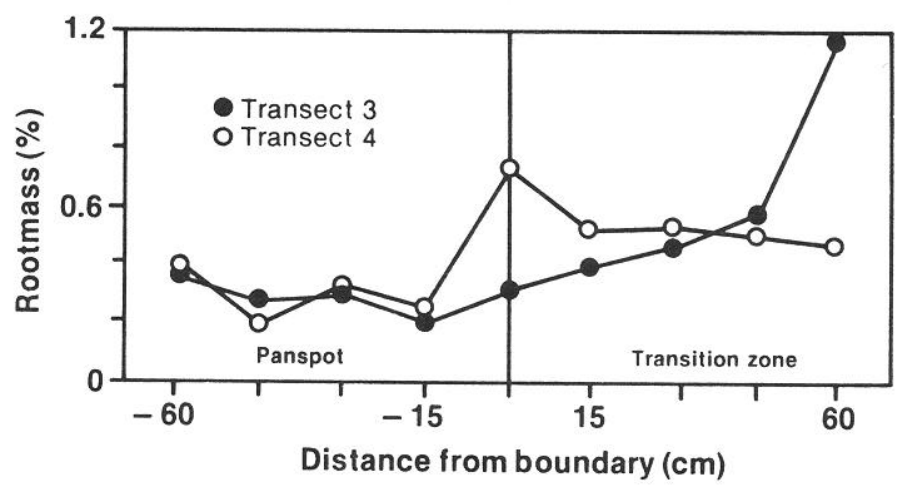

Fig. 2. Rootmass comparisons (as percent of dry soil weight) between transects 3 and 4 at $\mathbf{0 - 5} \mathrm{cm}$ depth as a function of distance on transect.

had only slightly higher values in the transition zone with a maximum found on the boundary.

\section{Discussion}

\section{Vegetation Analyses}

Forage yield, litter cover, and species composition vary markedly for panspot, transition zone, and Belfield soils. The distinctive range communities are in close proximity and are characteristic of sodium-affected landscapes (Sandoval and Reichman 1971, White et al. 1981). Salt tolerant species identified on panspot and transition zone soils of this study were widely recognized on other sodium-affected soils of the Northern Great Plains and in soils in big sagebrush communities (Artemisia tridentata tridentata Nutt.) of the Great Basin Physiographic Province (Hugie and Passey 1964; Eckert et al. 1978, 1986).

Increased litter in transition zone areas creates higher albedo, which has been reported to affect substantial changes in both the thermal regime of soils and the resultant soil moisture status (Oke 1978). Litter also acts as a mulch, reducing the amount of moisture lost from the soil by damping maximum and minimum soil surface air temperatures and increasing humidity. The mulch effect was demonstrated by Evans and Young (1970) in their study on population dynamics in cheatgrass (Bromus tectorum L.). These microsite properties may maintain a higher humidity and a more moderate thermal regime in transition zones as compared to panspot soils.

Cryptogams were observed to be an integral vegetative component in transition zone soils (Fig. 3). Nostoc spp. were the

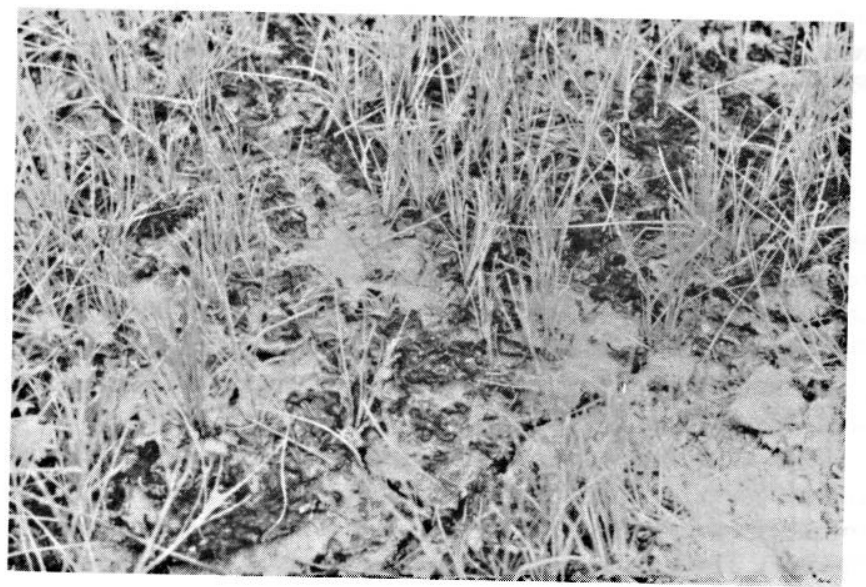

Fig. 3. Cryptogamic vegetation (Nostoc spp.) in a transition zone (note polygonal cracking). 
dominant cryptogam (T. Esslinger, personal communication). Cryptogams have been extensively studied in the Great Basin Physiographic Province; Anderson et al. (1982) state that the success of algae and fungi on saline sites is "undoubtedly related to physiologic tolerance." The presence of algal species has been noted locally in panspot soils by White et al. (1981). In this study algal growth seems adapted to transition zone areas; little algae was observed in panspots.

Polygonal cracking was observed in transition zone soils in preliminary field work (Hopkins et al. 1987b), and close inspection of the landscape during this study revealed that polygonal cracking was restricted to transition zone soils. Soil microtopography, especially cracking, was shown by Harper et al. (1965) to be a major factor controlling seed germination, because microtopographic variations "determine the frequency on the soil surface of microsites sufficiently humid for germination". In an extensive sampling of natural vegetation on crusted Aridisols in Nevada, Eckert et al. (1986) observed greater plant densities in trenches and polygonal cracks than on adjacent crusted soils.

\section{Root Density Distribution}

We believe the transition zones are not ephemeral phenomenon as evidenced by significantly higher rootmass values in transition zones compared to panspots for the 0 to $5 \mathrm{~cm}$ depth. Increased rooting activity results in increased organic matter contents and available water capacities in transition zone soil surfaces. Belfield soils are markedly different from panspot and transition zone soils and exhibit a 4-fold increase in root biomass in the 0 to $30 \mathrm{~cm}$ depth.

The presence of roots in panspots poses a question of origin. There is a possibility that rootmass values reflect sporadic growth of halophytic vegetation in moist years. The rare occasion of moisture in panspots when biotic activity is high, however, suggests that organic matter decomposition would be minimal. Alternatively, these roots may be relict features. Johnson et al. (1985) have shown that panspots are "erosional features that tend to move upslope". The panspots in this study are similar features; roots found in these panspots may have developed under different soil conditions and exist in a somewhat preserved state.

\section{Gradient Transect Analysis}

The number of transects with negative regression coefficients in the 0 to $5 \mathrm{~cm}$ depth class indicates a strong trend supporting our hypothesis of reduced soil EC in transition zones (Table 5). Vegetation establishment and growth in transition zones may increase infiltration and slowly improve soil structure resulting in lower levels of soil salinity. Supporting evidence for this process was reported by Hopkins et al. (1990). Significant reductions for both depth to gypsum and weighted soil EC in transition zones were obtained from soil pedons sampled uniformly on this study site. Vegetation establishment in transition zones, however, may simply reflect random distribution of zones of lower soil salinity in panspot soils; seeds are preferentially established where osmotic stress is minimized.

Lewis et al. (1959) used radioactive sulfur to trace soil moisture movement in panspot soils and demonstrated that "soil moisture moved into the panspot soil at some undetermined depth from the surrounding associated soil". The gradient for water flow was caused by the very low osmotic/matric potential for the panspot soil compared to adjacent soils characterized by relatively rapid, downward water flow. These adjacent soils, similar to Belfield soils in our study, act essentially as recharge zones. Water is transferred through the solum to saline, impermeable substrata, and becomes concentrated, following the water potential gradient to panspots, which are the hydraulic discharge zones. As the discharge zones dry, polygonal cracks form due to the high percentage of smectite.
The polygonal cracking that we observed in transition zone soils does not appear to be caused by elevational gradients between panspots and transition zones. Results from comparisons of microtopographic elevation indicate less than $5 \mathrm{~mm}$ difference between panspot and transition zone surfaces. In many cases transition zones were the same elevation as adjacent panspot surfaces. Differential ponding following precipitation does not appear to be a factor in development of polygonal cracking or reductions in soil salinity in transition zones.

Continued maintenance of plant growth in transition zones fosters the beneficial properties mentioned earlier and effects the reversal of water flow in transition zones from discharge to recharge. The initiation of a leaching profile in transition zones is the first step towards natural reclamation of the panspot/transition soil complex.

\section{Literature Cited}

Alzubaidi, A., and G.R. Webster. 1983. Ion pairs in a solonetzic soil. Can. J. Soil Sci. 63:479-484.

Anderson, D.C., K.T. Harper, and R.C. Holmgren. 1982. Factors influencing development of cryptogramic soil crust in Utah deserts. J. Range Manage. 35:180-185.

Arny, A.C., and A.R. Schmid. 1942. A study of the inclined point quadrat method of botanical analysis of pasture mixtures. J. Amer. Soc. Agron. 34:238-247.

Chapman, H.D., and P.F. Pratt. 1961. Methods of analysis for soils, plants, and waters. Spec. Pub. 4034. Div. Agr. Sci., Univ. of Calif., Berkeley.

Dahnke, W.C. (ed). 1980. Recommended chemical soil test procedures for the North-Central Region. Bull. 499. North Dakota Agr. Exp. Sta., Fargo.

Day, P.R. 1965. Particle fractionation and particle size analysis. p. 545-567. In: C.A. Black et al. (ed.) Methods of soil analysis. Part 1. Agronomy 9 Amer. Soc. Agron. Madison, Wisc.

Eckert, R.E., F.E. Peterson, M.S. Meurisse, and J.L. Stephens. 1986. Effects of soil-surface morphology on emergence and survival of seedlings in big sagebrush communities. J. Range Manage. 39:414-420.

Eckert, R.E., M.K. Wood, W.H. Blackburn, F.F. Peterson, J.L. Stephens, and M.S. Meurisse. 1978. Effects of surface-soil morphology on improvement and management of some arid and semiarid rangelands. p. 299-302. In: (ed. D.H. Hyder) Proc. 1st Internat. Rangel. Congr., Soc. Range Manage., Denver, Colo.

Evans, R.A., and J.A. Young. 1970. Plant litter and establishment of alien annual weed species in rangeland communities. Weed Sci. 20:350-356.

Great Plains Flora Association. 1986. Flora of the Great Plains. Univ. Kansas Press. Lawrence.

Harnett, D.L. 1970. Introduction to statistical methods. Addison-Wesley, Reading, Mass.

Harper, J.L., J.T. Williams, and G.R. Sanger. 1965. The behavior of seed in soil. 1 . The heterogeneity of soil surfaces and its role in determining the establishment of plants. J. Ecol. 53:273-286.

Hopkins, D.G., J.L. Richardson, and M.D. Sweeney. 1987a. Composition comparisons in sodic map unit delineations on the Dickinson Experiment Station Ranch Headquarters, North Dakota. Soil Surv. Horiz. 28:46-50.

Hopkins, D.G., M.D. Sweeney, D.R. Kirby, and J.L. Richardson. 1987b. Effects of revegetation upon selected soil chemical properties in sodiumaffected soils of western North Dakota. Agron. Abstr. p. 225.

Hopkins, D.G., M.D. Sweeney, and J.L. Richardson. 1990. Dispersive erosion and panspot genesis in western North Dakota. Soil Sci. Soc. Amer. J. (in press).

Hugie, V.K., and H.B. Passey. 1964. Soil surface patterns of some semiarid soils in northern Utah, southern Idaho, and northeastern Nevada. Soil Sci. Soc. Amer. Proc. 28:786-792.

Johnson, W.F., M.J. Mausbach, E.E. Gamble, and R.E. Nelson. 1985. Natric horizons on some erosional landscapes in northwestern South Dakota. Soil Sci. Soc. Amer. J. 49:947-952.

Kellogg, C.E. 1934. Morphology and genesis of the solonetz soils of western North Dakota. Soil Sci. 38:483-500.

Kirby, U.R., M.F. Pessin, and G.K. Clambey. 1986. Disappearance of forage under short duration and seasonlong grazing. J. Range Manage. 39:496-500. 
Lewis, G.C., J.V. Jordon, and M.A. Fosberg. 1959. Tracing moisture movement in slick spot soils with radiosulfur. Part II. Soil Sci. Soc. Amer. Proc. 23:206-210.

Lewis, G.C., and J.L. White. 1964. Chemical and mineralogical studies on slick spot soils in Idaho. Soil Sci. Soc. Amer. Proc. 28:805-808.

Mogen, C.A., J.E. McClelland, J.S. Allen, and F.W. Schroer. 1959. Chestnut, Chernozem and associated soils of western North Dakota. Soil Sci. Soc. Amer. Proc. 23:56-60.

Munn, L.C., and M.M. Boehm. 1983. Soil genesis in a NatrargidHaplargid complex in northern Montana. Soil Sci. Soc. Amer. J. 47:1186-1192.

Oke, T.R. 1978. Boundary layer climates. Methuen and Co. New York.

Peech, M. 1965. Hydrogen-ion activity. In: C.A. Black et al. (ed.). Methods of soil analysis. Part 1. Agron. 9:545-567.

Rhoades, J.D. 1982. Soluble salts. In: A.L. Page et al. (ed.) Methods of soil analysis. Part 2. (2nd Ed.) Agronomy 9:167-179. Amer. Soc. Agron. Madison, Wisc.

SAS Institute. 1985. SAS users guide: statistics, Version 5. Cary, NC.

Sandoval, F.M., M.A. Fosberg, and G.C. Lewis. 1959. A characterization of the Sebree-Chilcott soil series association (slick spots) in Idaho. Soil Sci. Soc. Amer. Proc. 23:317-320.
Sandoval, F.M., and G.A. Reichman. 1971. Some properties of solonetzic (sodic) soils in western North Dakota. Can. J. Soil Sci. 51:143-155.

Soil Survey Staff. 1951. Soil survey manual. USDA Handb. 18. U.S. Government Printing Office, Washington, D.C.

Stuart, D.M., G.E. Schuman, and A.S. Dylla. 1971. Chemical characteristics of coppice dune soils in Paradise Valley, Nevada. Soil Sci. Soc. Amer. Proc. 35:605-611.

U.S. Salinity Laboratory Staff. 1954. Diagnosis and improvement of saline and alkali soils. Agr. Handb. 60. U.S. Government Printing Office, Washington, D.C.

USDA Soil Conservation Service. 1984. Missouri Slope vegetation zoneguide to range sites. North Dakota Tech. Guide Notice ND 35, Bismarck.

Ward, K.J., B. Klepper, R.W. Rickman, and R.R. Allmaras. 1978. Quantitative estimation of living wheat-root lengths in soil cores. Agron. J. 70:675-677.

White, E.M., R.F. Gartner, and R. Butterfield. 1981. Range claypan soil improvement: response from furrowing and ripping in northwestern South Dakota. J. Range Manage. 34:119-125.

Wright, R.M., J. Scharar, and S. Tillotson. 1982. Soil Survey of Dunn County, North Dakota. U.S. Government Printing Office, Washington, D.C. 